\title{
Estimation of Missing Data and Maps of the Behaviour of Total Precipitation in Northern Colombia
}

\author{
Fernando Jove Wilches*1, Rodrigo Hernández Avila ${ }^{1}$ and Álvaro Rafael Caballero Guerrero ${ }^{2}$ \\ ${ }^{1}$ Department of Civil Engineering, Universidad de Sucre, Sincelejo, Sucre, Colombia. \\ ${ }^{2}$ Department of Civil and Environmental Engineering, Universidad del Norte, Barranquilla, Colombia.
}

ORCIDs: 0000-0002-2080-4036 (Fernando), 0000-0003-3178-8075 (Rodrigo), 0000-0002-3567-9135 (Álvaro)

\begin{abstract}
The climatic conditions of a territory are a key element in the development of multiple types of projects, hence it is necessary to have relevant information that helps determine and simulate the future climate conditions that may influence such projects. At this point, the important thing is to have reliable and complete weather information records. Unfortunately, in Colombia, being able to find this type of information is not so simple, and in general the climatological data are incomplete for reasons such as failures or non-calibration in the measurement instruments, errors in the recording of measurements, meteorological extremes and difficulty in the access of the measurement areas. Hence, the determination of the missing data in the records of the climatological stations becomes a necessary question to complete the incomplete historical series. A common case is the missing data in rainfall stations, which are essential in hydrological simulation studies in order to obtain optimal hydraulic solutions. Therefore, it is almost mandatory to properly fill in missing data before performing any analysis on such data. This work presents the determination of missing data of total precipitation of 40 meteorological measurement stations located in the north of Colombia. The series analysed cover a period of 40 years of observations from 1980 to 2019, obtained by the Instituto de Hidrología, Meteorología y Estudios Ambientales (IDEAM). The estimation of missing data was carried out using Multiple Linear Regression (MLR), which allows estimating missing data based on nearby records that correlate with said data. The Beale - Little algorithm is applied which is based on the RLM method, using all the available information and leads to a simultaneous estimation of the missing values. The estimated precipitation dataset is useful for future hydrological analysis of studies that require meteorological forecasts in regions with losses of hydrological information, such as the meteorological stations located in the north of Colombia.
\end{abstract}

Keywords: Monthly rainfall, Missing data, Extreme rainfall, Multiple Linear Regression, Beale-Little algorithm.

\section{INTRODUCTION}

Hydrology is the science that deals with water, its occurrence, its circulation, distribution, its properties and its relationship with the environment and living beings [1]. Hydrology allows a rational and efficient use of the planet's water resources.
Through this, it is possible to plan and carry out studies that lead to the proper management of the water resources of a region.

Hydrology provides the technical and scientific elements that will allow you to adequately understand the water cycle [2]. These scientific methods generally require input data according to the models used and the specific conditions of the project. Rainfall is considered a main variable in hydrological studies, as it is the most important source for calculating the water balance and generating early warnings for risk of drought or flooding in a geographic region [3].

Rainfall analyses require continuous, homogeneous data that cover the maximum possible time interval. Unfortunately, the database available in the collection centres, most of the time, presents missing information due to the absence of reading, failure of the recording instrument, transcription error, among others, which limits the analyses and many times, it is constituted as a source of error [3]. Multiple Linear Regression (MLR) is a statistical technique that can be used in hydrology with the intention of determining the missing data on runoff characteristics, calculated in basins with hydrometric to sites or basins where such information is necessary and there are no gauges. [4]. In a complete way, the Beale-Little algorithm is used to simultaneously estimate the missing data in the records of the rainfall stations of the geographical area under study. With the use of this technique it is possible to obtain the data lost in the series of rainfall data, in order to carry out more reliable hydrological analyses and studies.

Once an area or region of the territory has been evaluated, the results of the analyses can be presented graphically. Being one of the most common and practical forms, show them in spatial distribution schemes where the hydrological variables analysed are represented. In the case of rainfall, the use of GIS tools for this purpose has become very popular. To carry out this, it is necessary to know the spatial variation in the study area, for which precipitation fields must be constructed, using interpolation methodologies, among which there is the Kriging method and the IDW method (Inverse Distance Weighted) [6]. Once the modelling has been carried out, the diagrams will be obtained showing the distribution and spatial interpolation of the rainfall in the study areas.

The study area presents different hydrological conditions throughout the entire territory, where there are geographically mountainous areas and others with swampy areas and river 
discharge points, making their environmental conditions very varied. The information analysed includes precipitation data from 40 stations that have been active in the last 40 years and are located in the department of Sucre. The historical records of total rainfall were obtained from the data of the measurements of rainfall stations that rest in the Instituto de Hidrología, Meteorología y Estudios Ambientales (IDEAM).

The objective of this work is to present the RLM method through the use of the Beatle-Litle algorithm, for the determination of missing values of total rainfall in the stations located in the department of Sucre. From this, it was possible to fill in the missing rainfall for the forty stations in the study period, which was 40 years. In this way, it is possible to obtain reliable information that hydraulic researchers and designers require to develop their projects. Similarly, distribution maps of average and maximum rainfall of the study area were created. This allows the obtained results to be viewed in a clearer way and is of great use to professionals interested in studying the precipitation conditions of the area under study.

\section{EXPERIMENTAL DESIGN, MATERIALS AND METHODS}

\section{II.I Study area description}

The Department of Sucre is located in the Colombian Caribbean plain, north of the Central and Western mountain ranges, it has an area of 10,364 square kilometres. It limits to the north and east with the Department of Bolívar, to the south with the Departments of Antioquia and Córdoba, to the west with the Department of Córdoba and to the northeast with the Caribbean Sea. A little more than a third of its territory forms the flood-prone depression of the Bajo Magdalena, Cauca and San Jorge rivers, characterized by numerous swamps, especially along the San Jorge river. To the northwest, on the other hand, a strip of hills can be seen, corresponding to the San Jacinto or Montes de María mountains. Between these hills and the San Jorge depression lie more or less flat savannas. In the Department of Sucre the climate is warm, dry towards the sea and humid towards the depression. The various reliefs in the Department of Sucre have a warm thermal floor with temperatures that range between $25.5^{\circ} \mathrm{C}$ and $28.7^{\circ} \mathrm{C}$ average per year. The precipitation regime is determined by the geographical location, and by the influence of some factors, such as atmospheric circulation, relief, the interaction between land and sea and the influence of jungle or wooded areas. In Sucre, the annual average rainfall varies between $1,000 \mathrm{~mm}$ for the less humid areas in the north, up to $2,800 \mathrm{~mm}$ in the rainiest areas of the south [7].

\section{II.II Material and methods}

The determination of the missing rainfall data was carried out by applying the Beale-Little algorithm, which is a Multivariate Analysis (AM) technique that allows to simultaneously estimate the missing data in records of hydrometric or pluviometric stations of a geographical area, which show a significant correlation, but do not have persistence. The technique is appropriate to estimate missing data that were lost randomly, that is, when there was an absence of the operator or a temporary suspension, maintenance or poor calibration of the equipment, or, due to improvements in the installation [8] [9].

The first step in the methodology is to collect the available information and organize it in a matrix arrangement where the rows represent the recording periods and the columns represent the meteorological stations, adding an asterisk to the missing data or leaving the spaces in blanks. Next, the initial substitution of the missing data is made, for this, the arithmetic average of each column is calculated and this value is replaced in the spaces with missing data. From these, the MLR for each record is calculated and the missing data is estimated. After applying the RLM, the differences between the old data and the new data are calculated, which would constitute the first cycle of the Beale-Little algorithm. This process continues for the number of cycles that is necessary until the difference between the new data and the previous one takes a sufficiently small value or is almost negligible; so that if this degree of precision is not reached, the new estimates are replaced by the old ones and new estimates are made using the same procedure.

The mathematical formulation of the RLM [10] [11] is shown below. It is assumed that there are $n$ observations of $\mathrm{Y}, \mathrm{X}_{1}$, $\mathrm{X}_{2}, \ldots, \mathrm{X}_{\mathrm{p}}$, considering that there are $\mathrm{p}$ independent variables or regressors of the Regression, whose model is the following:

$$
Y=\beta_{0}+\beta_{1} X_{1}+\beta_{2} X_{2}+\cdots+\beta_{p} X_{p}+\varepsilon
$$

In matrix notation, we have:

$$
Y=X \cdot \beta+\varepsilon
$$

$$
\begin{aligned}
& Y=\left[\begin{array}{c}
Y_{1} \\
Y_{2} \\
\vdots \\
Y_{n}
\end{array}\right] X=\left[\begin{array}{ccccc}
1 & X_{11} & X_{12} & \cdots & X_{1 p} \\
1 & X_{21} & X_{22} & \cdots & X_{2 p} \\
\vdots & \cdots & \cdots & \cdots & \vdots \\
1 & X_{n 1} & X_{n 2} & \cdots & X_{n p}
\end{array}\right] \\
& \beta=\left[\begin{array}{c}
\beta_{0} \\
\beta_{1} \\
\vdots \\
\beta_{n}
\end{array}\right] \varepsilon=\left[\begin{array}{c}
\varepsilon_{1} \\
\varepsilon_{2} \\
\vdots \\
\varepsilon_{n}
\end{array}\right]
\end{aligned}
$$

The matrix $X$ contains the $X_{i j}$ observations of the meteorological data, showing the $i_{\text {-th }}$ periods of the observations and the $\mathrm{j}_{\text {-th }}$ independent variables. The method seeks that the sum of the squared errors $\left(\varepsilon_{i}\right)$ is minimized according to the expression:

$$
\sum_{i=1}^{n} \varepsilon_{i}^{2}=\sum_{i=1}^{n}\left(Y_{i}-\beta_{0}-\beta_{1} X_{i 1}-\beta_{2} X_{i 2}-\ldots-\beta_{p} X_{i p}\right)^{2}
$$

When differentiating the right hand side of equation 3 , based on $\beta_{0}, \beta_{1}, \ldots, \beta_{p}$ separately and equaling to zero, this produces $\mathrm{p}$ equations with $\mathrm{p}$ unknown parameters, and is called normal equations. This, written in matrix notation, looks like this:

$$
X^{T} \cdot X \cdot \beta=X^{T} . Y
$$

The solution of equation 4 for the $\beta$ i can be expressed from Equation 5:

$$
\beta=\left(X^{T} \cdot X\right)^{-1} \cdot X^{T} . Y
$$




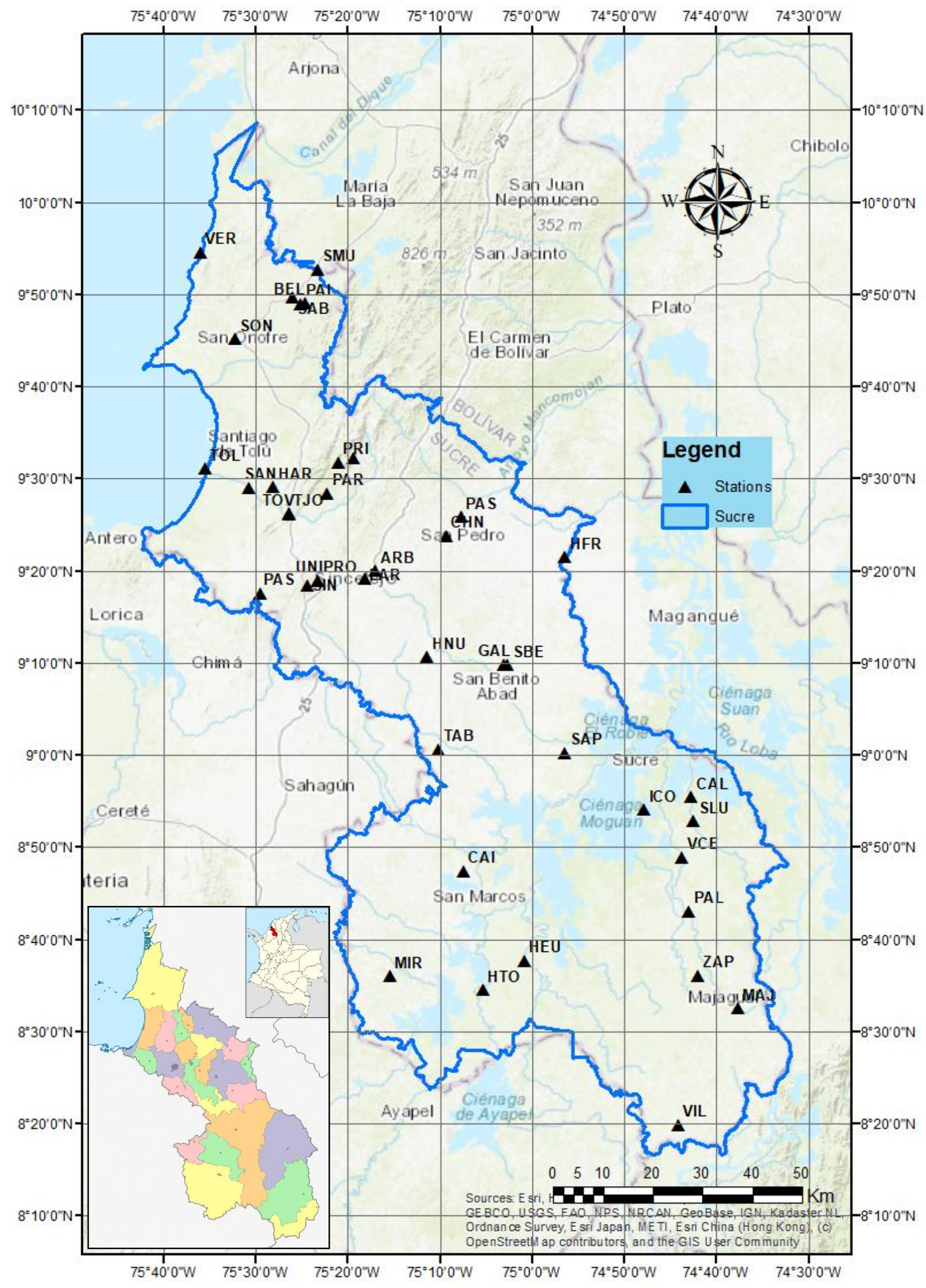

Fig 1. Location of meteorological stations belonging to the department of Sucre 
In equation $5, X$ is the matrix with the observations and variables, $Y$ is the vector of dependent observations, $X^{T}$ is the transpose matrix of $X$, and $\left(X^{T} . X\right)^{-1}$ is the matrix inverse of the matrix constructed through $X^{T} . X$.

Additionally, Figures were created showing the average and maximum rainfall of the stations, in order to generate an extrapolation of the data and observe the behavior of rainfall based on the historical series with missing data filled in, being able to observe the behavior of average rainfall over the 40 -year Study period.

To carry out this process, the GIS computing tool, ArcMap, was used, for which the geographic location data of the stations were imported into the program, as well as the values related to the average and maximum precipitation. Additionally, layers were imported to limit the study area (the department of Sucre) and other layers to give relief to neighboring places and general information.

The Kriging method was used to perform the spatial interpolation of the precipitation variable. This is a geostatistical method, which relates mathematics to earth sciences, therefore being ideal for estimating the rainfall data obtained from the measurement of the rain gauge. The Kriging method works with statistical models that involve autocorrelation [6].

Autocorrelation allows spatial interpolation to occur, which generally occurs when estimating a regionalized value at unsampled points, based on the weight of the regionalized values that were observed. Equation 6 shows the mathematical model that governs spatial interpolation [6].

$$
Z g=\sum_{i=1}^{n s} \lambda_{i} Z s i
$$

In equation $6, Z g$ is the interpolated value in the requested areas or points, $Z s i$ is the value observed at point $i, n s$ is the total number of points observed and $\lambda i$ is the weight that contributes to the interpolation.

Within ArcMap this method (Kriging) was selected, because it has some advantages over the traditional interpolation methods built into GIS. If the assumptions of the theory hold, the method is less arbitrary compared to others. A very important difference to emphasize is that the weights used in the method are determined by the variogram and the configuration of the observed data [12].
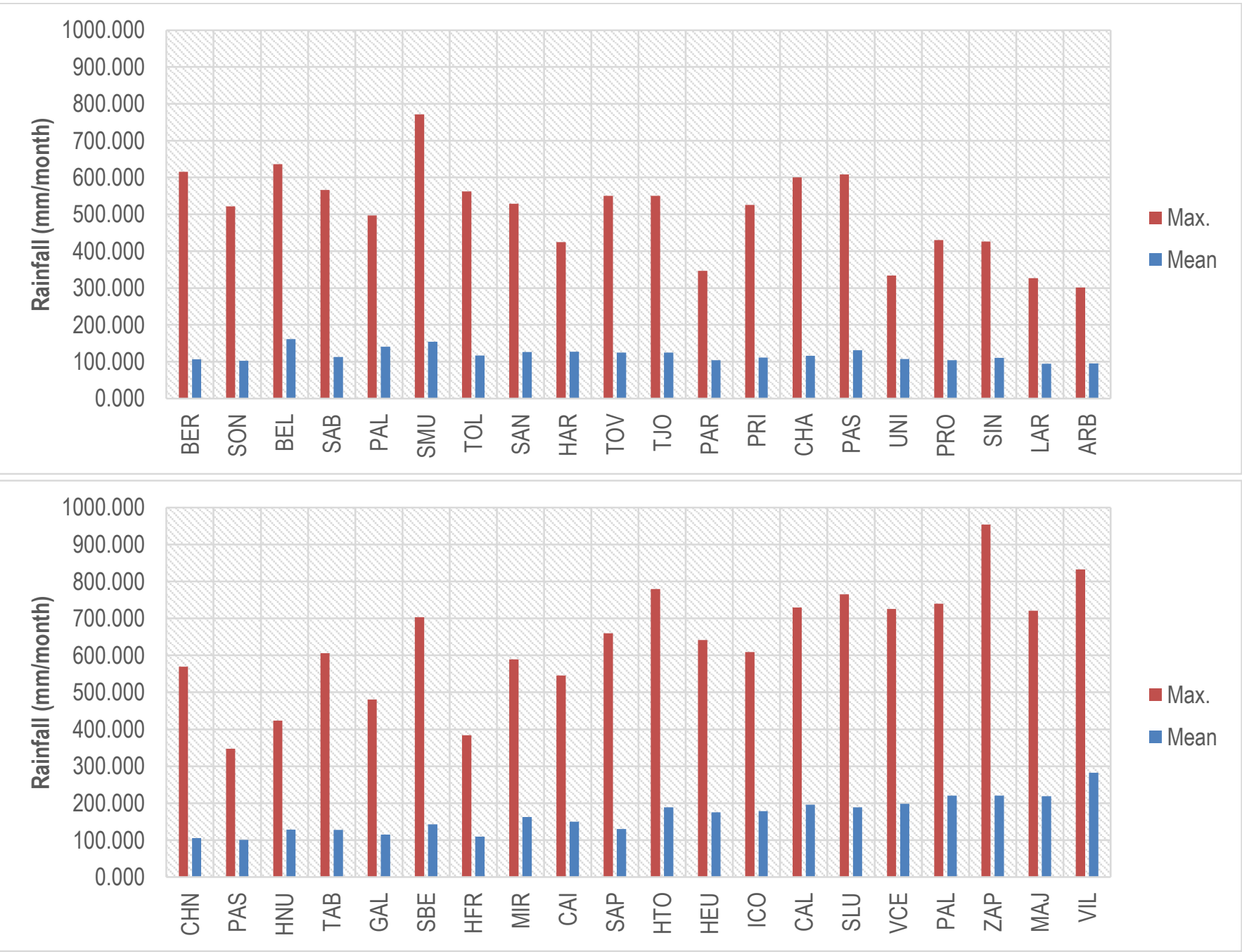

Fig. 2. Mean and maximum values of monthly rainfall. 
Table 1. General data of the Meteorological Stations

\begin{tabular}{|c|c|c|c|c|c|c|c|}
\hline ID & NUMBER & STATION NAME & CODE & ALTITUDE & LATITUDE & LONGITUDE & MUNICIPALITY \\
\hline 1 & 13090030 & BERRUGAS & BER & 1 & 9.91027778 & -75.6005556 & San Onofre \\
\hline 2 & 13090020 & SAN ONOFRE & SON & 55 & 9.75416667 & -75.5380556 & San Onofre \\
\hline 3 & 13090080 & BELEN HACIENDA & BEL & 60 & 9.81944444 & -75.4102778 & San Onofre \\
\hline 4 & 13090010 & SABANETICA & SAB & 1 & 9.82888889 & -75.4327778 & San Onofre \\
\hline 5 & 13090110 & PALO ALTO & PAL & 50 & 9.81750000 & -75.4183333 & San Onofre \\
\hline 6 & 29030380 & SABANAS DE MUCACAL & SMU & 10 & 9.87980556 & -75.3886944 & San Onofre \\
\hline 7 & 13090070 & TOLU & TOL & 2 & 9.51916667 & -75.5911111 & Tolú \\
\hline 8 & 13090090 & SANTA ANGELA HACIENDA & SAN & 20 & 9.48527778 & -75.5125000 & Tolú \\
\hline 9 & 13090100 & ARGENTINA LA HACIENDA & HAR & 20 & 9.48583333 & -75.4686111 & Tolú Viejo \\
\hline 10 & 13090050 & TOLUVIEJO & TOV & 60 & 9.43800000 & -75.4400000 & Tolú Viejo \\
\hline 11 & 13097010 & TOLUVIEJO & TJO & 59 & 9.43700000 & -75.4390000 & Tolú Viejo \\
\hline 12 & 13090060 & PARAISO EL & PAR & 100 & 9.47388889 & -75.3708333 & Colosó \\
\hline 13 & 13095020 & PRIMATES & PRI & 200 & 9.53013889 & -75.3513611 & Colosó \\
\hline 14 & 13090040 & CHALAN & CHA & 100 & 9.53861111 & -75.3225000 & Chalán \\
\hline 15 & 13090230 & PASTORA LA & PAS & 58 & 9.29333333 & -75.4919444 & Sincelejo \\
\hline 16 & 25025270 & UNISUCRE & UNI & 160 & 9.31638889 & -75.3875000 & Sampués \\
\hline 17 & 25025350 & PUERTA ROJA & PRO & 160 & 9.31638889 & -75.3875000 & Sincelejo \\
\hline 18 & 25020130 & SINCELEJO & SIN & 200 & 9.30816667 & -75.4068333 & Sincelejo \\
\hline 19 & 25020400 & LIBRA ARRIBA & LAR & 180 & 9.32055556 & -75.3036111 & Betulia \\
\hline 20 & 25025080 & APTO RAFAEL BARVO & ARB & 166 & 9.33388889 & -75.2830556 & Corozal \\
\hline 21 & 25020390 & CHARCON & $\mathrm{CHN}$ & 150 & 9.39722222 & -75.1558056 & Los Palmitos \\
\hline 22 & 25020190 & PUERTO ASIS & PAS & 200 & 9.43194444 & -75.1291667 & Los Palmitos \\
\hline 23 & 25020990 & HATO NUEVO & $\mathrm{HNU}$ & 80 & 9.17833333 & -75.1902778 & Corozal \\
\hline 24 & 25020750 & TABLITAS LAS & TAB & 60 & 9.01138889 & -75.1688889 & San Benito Abad \\
\hline 25 & 25021000 & GALERAS & GAL & 70 & 9.16500000 & -75.0508333 & Galeras \\
\hline 26 & 25025380 & SAN BENITO & SBE & 20 & 9.16388889 & -75.0447222 & San Benito Abad \\
\hline 27 & 25020860 & FRONTERA LA HACIENDA & HFR & 100 & 9.35944444 & -74.9408333 & Buenavista \\
\hline 28 & 25021660 & MIRASOL & MIR & 30 & 8.60083333 & -75.2572222 & San Marcos \\
\hline 29 & 25020980 & CAIMITO & CAI & 20 & 8.79083333 & -75.1244444 & Caimito \\
\hline 30 & 25020760 & SANTIAGO APOSTOL & SAP & 25 & 9.00472222 & -74.9405556 & San Benito Abad \\
\hline 31 & 25021470 & TORNO EL HACIENDA & HTO & 60 & 8.57638889 & -75.0897222 & San Marcos \\
\hline 32 & 25020740 & EUREKA HACIENDA & HEU & 20 & 8.62916667 & -75.0147222 & San Marcos \\
\hline 33 & 25021560 & ISLA DEL COCO & ICO & 20 & 8.90277778 & -74.7986111 & Sucre (Sucre) \\
\hline 34 & 25021360 & CAMPO ALEGRE & CAL & 20 & 8.92472222 & -74.7119444 & Sucre (Sucre) \\
\hline 35 & 25021370 & SAN LUIS & SLU & 20 & 8.88166667 & -74.7080556 & Sucre (Sucre) \\
\hline 36 & 25020500 & VILLA CECILIA HACIENDA & VCE & 50 & 8.81611111 & -74.7294444 & Sucre (Sucre) \\
\hline 37 & 25020790 & PALMARITO & PAL & 50 & 8.71888889 & -74.7177778 & Majagual \\
\hline 38 & 25020820 & ZAPATA & ZAP & 50 & 8.60277778 & -74.6997222 & Majagual \\
\hline 39 & 25025240 & MAJAGUAL & MAJ & 26 & 8.54269444 & -74.6273333 & Majagual \\
\hline 40 & 25020940 & VILLANUEVA & VIL & 45 & 8.33277778 & -74.7355556 & Guaranda \\
\hline
\end{tabular}


International Journal of Engineering Research and Technology. ISSN 0974-3154, Volume 13, Number 10 (2020), pp. 2935-2942

(C) International Research Publication House. https://dx.doi.org/10.37624/IJERT/13.10.2020.2935-2942

Table 2. Statistical Description of the Data of the Meteorological Stations

\begin{tabular}{|c|c|c|c|c|c|}
\hline CODE & Observations & $\begin{array}{c}\text { Minimum } \\
\text { (mm/month) }\end{array}$ & $\begin{array}{c}\text { Maximum } \\
(\mathrm{mm} / \mathrm{month})\end{array}$ & $\begin{array}{c}\text { Mean } \\
\text { (mm/month) }\end{array}$ & $\begin{array}{c}\text { Standard deviation } \\
(\mathrm{mm} / \mathrm{month})\end{array}$ \\
\hline BER & 480 & 0.161 & 615.500 & 106.155 & 103.801 \\
\hline SON & 480 & 0.554 & 521.600 & 102.349 & 83.100 \\
\hline BEL & 480 & 0.100 & 636.208 & 161.092 & 113.493 \\
\hline SAB & 480 & 0.080 & 566.000 & 113.084 & 98.949 \\
\hline PAL & 480 & 0.233 & 497.167 & 140.471 & 97.700 \\
\hline SMU & 480 & 0.304 & 771.125 & 154.512 & 113.475 \\
\hline TOL & 480 & 0.277 & 562.500 & 116.658 & 101.510 \\
\hline SAN & 480 & 0.708 & 528.667 & 126.011 & 104.181 \\
\hline HAR & 480 & 0.312 & 425.017 & 127.547 & 95.134 \\
\hline TOV & 480 & 0.100 & 550.000 & 124.710 & 98.335 \\
\hline TJO & 480 & 0.055 & 550.000 & 125.031 & 98.848 \\
\hline PAR & 480 & 0.400 & 346.742 & 103.775 & 75.258 \\
\hline PRI & 480 & 0.736 & 525.858 & 111.484 & 89.300 \\
\hline $\mathrm{CHA}$ & 480 & 0.200 & 600.375 & 116.309 & 94.523 \\
\hline PAS & 480 & 0.040 & 608.417 & 131.407 & 103.449 \\
\hline UNI & 480 & 0.273 & 334.194 & 107.471 & 75.653 \\
\hline PRO & 480 & 1.000 & 430.000 & 104.139 & 72.846 \\
\hline SIN & 480 & 1.220 & 426.000 & 110.153 & 77.261 \\
\hline LAR & 480 & 0.896 & 326.690 & 94.822 & 71.803 \\
\hline ARB & 480 & 0.088 & 301.700 & 95.164 & 68.821 \\
\hline $\mathrm{CHN}$ & 480 & 0.468 & 569.500 & 105.440 & 80.147 \\
\hline PAS & 480 & 0.175 & 347.375 & 100.986 & 70.993 \\
\hline $\mathrm{HNU}$ & 480 & 1.000 & 423.208 & 128.674 & 96.774 \\
\hline $\mathrm{TAB}$ & 480 & 0.500 & 605.500 & 127.729 & 98.497 \\
\hline GAL & 480 & 0.331 & 480.667 & 115.122 & 92.116 \\
\hline SBE & 480 & 0.146 & 703.158 & 143.126 & 113.750 \\
\hline HFR & 480 & 0.583 & 383.583 & 109.328 & 79.578 \\
\hline MIR & 480 & 0.723 & 589.000 & 162.386 & 126.330 \\
\hline CAI & 480 & 0.430 & 545.375 & 150.230 & 117.609 \\
\hline SAP & 480 & 0.200 & 660.000 & 130.086 & 109.792 \\
\hline HTO & 480 & 0.391 & 779.792 & 188.760 & 154.414 \\
\hline HEU & 480 & 1.000 & 641.792 & 175.472 & 134.026 \\
\hline $\mathrm{ICO}$ & 480 & 1.458 & 608.875 & 178.659 & 137.756 \\
\hline CAL & 480 & 0.886 & 729.375 & 195.968 & 155.168 \\
\hline SLU & 480 & 0.898 & 765.417 & 188.797 & 150.821 \\
\hline VCE & 480 & 0.106 & 725.292 & 198.295 & 155.765 \\
\hline PAL & 480 & 0.036 & 740.000 & 220.580 & 175.848 \\
\hline ZAP & 480 & 0.997 & 954.042 & 220.417 & 169.662 \\
\hline MAJ & 480 & 0.700 & 720.917 & 218.938 & 163.761 \\
\hline VIL & 480 & 1.417 & 832.167 & 282.592 & 199.068 \\
\hline
\end{tabular}

\section{RESULTS}

This section contains Figures and Tables of the precipitation data that were analyzed from the information obtained from 40 meteorological stations located within the territory of the Department of Sucre (Colombia).
Fig. 1 shows the map of the location of the department of Sucre and the location of the meteorological stations that were selected for this work. The names, codes, the geographic coordinates of the location, the elevations and the municipalities where the IDEAM meteorological stations are located were tabulated in Table 1 . The information on the 
statistical description of the data of the selected meteorological stations is shown in Table 2, where you can see the nomenclature given to each station, the number of observations considered during the study period (40 years), as well as the maximum, average values and the corresponding standard deviation, related to the Total monthly rainfall for each station.

Fig. 2 shows the historical average of the mean and maximum annual rainfall in the 40-year period for the department of Sucre. The stations are organized in a North-South direction, thus allowing us to look at their behavior.

In Fig. 3 and 4, a graphical representation has been made through the ArcMap program of the average and maximum precipitations of the area under study, in this way it can be easily appreciated which are the parts of the department where it has rained the most in the last 40 years and which have been the places with less precipitation, which gives an idea of the spatial and temporal distribution of the rains during the study period.



Fig. 3. Comportamiento de la precipitación promedio mensual en el departamento de Sucre

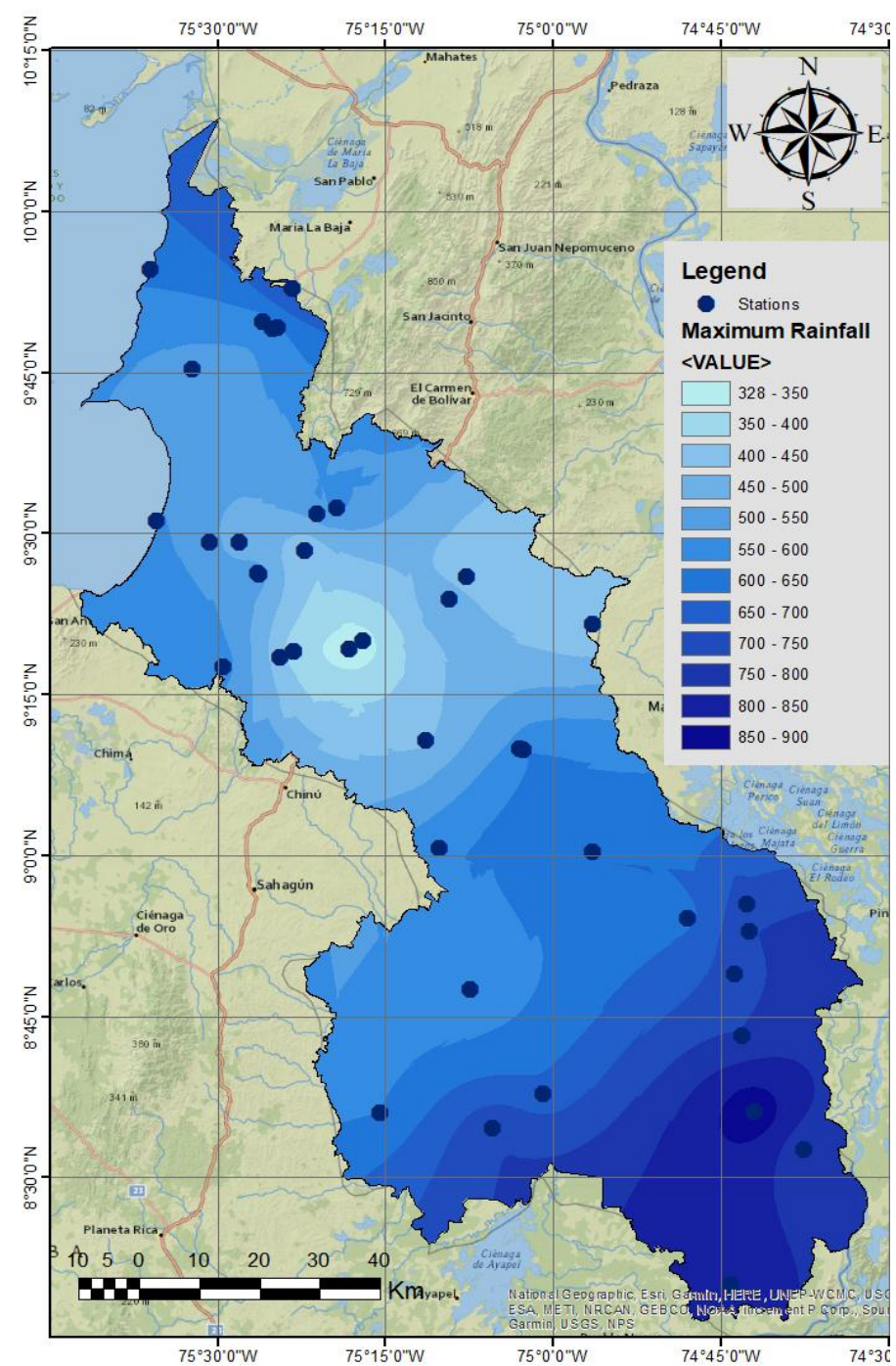

Fig. 4. Comportamiento de la precipitación máxima mensual en el departamento de Sucre

\section{CONCLUSIONS}

From the work carried out, the missing monthly precipitation data could be obtained for the 40 selected meteorological stations. This information is of particular interest to be taken as an essential input for the hydrological characterization of the engineering projects that are intended to be developed within the department of Sucre.

Additionally, maps were obtained that show the behavior of monthly average and maximum monthly rainfall in the department of Sucre, information that allows establishing the rainfall characteristics of a project, according to its geographic location.

\section{Acknowledgments}

The authors thank the Instituto de Hidrología, Meteorología y Estudios Ambientales (IDEAM) for providing the database containing the monthly and annual rainfall for historical periods of all the stations in the department of Sucre 
(Colombia). Authors also thank the engineer Edilberto Elias Contreras Sierra for the contributions made in the development of the manuscript.

\section{REFERENCES}

[1] Linsley R, Kohler M, Paulhus J. Hidrología para ingenieros, 2 ed. New York, McGraw-Hill, 1985.

[2] Legarda Burbano L, Viveros Zarama M. La importancia de la hidrología en el manejo de cuencas hidrográficas. Revista De Ciencias Agrícolas.1996;14(1y2). Disponible en https://revistas.udenar.edu.co/index.php/rfacia/article /view/1163? articlesBySameAuthorPage=3\#articlesBySa meAuthor

[3] Herrera C, Campos J, Carrillo J. Estimación de datos faltantes de precipitación por el método de regresión lineal: Caso de estudio Cuenca Guadalupe, Baja California, México. Investigación y Ciencia. 2017; 25 (71): 34-44. Disponible en https://www.redalyc.org/articulo.oa?id=67452917005

[4] Campos-Aranda D. Una aplicación hidrológica de la regresión lineal múltiple ponderada. Tecnología y ciencias del agua. 2016; 7 (4): 161-173. Disponible en http://www.scielo.org.mx/scielo.php?script=sci_arttext\& pid=S2007-24222016000400161\&lng=es\&nrm=iso

[5] Vargas A, Santos A, Cárdenas E, Obregón N. Análisis de la distribución e interpolación espacial de las lluvias en Bogotá, Colombia. Dyna. 2011; 78 (167): 151-159. Disponible en: https://www.redalyc.org/articulo.oa?id= 496/49622358017

[6] Ly S, Charles C, Degré A. Different methods for spatial interpolation of rainfall data for operational hydrology and hydrological modeling at watershed scale: a review, BASE. 2013: 17 (2).

[7] Banco de la Republica de Colombia, Documentos de trabajo sobre la economia regional. https://www.banrep.gov.co/docum/Lectura_finanzas/pdf /DTSER-63-VE.pdf , 2005 (accessed 9 September 2020)

[8] Beale EML, Little RJA. Missing values in multivariate analysis, Journal of Royal Statistical Society B. 1975; 37: 129-145. DOI; $\quad$ https://doi.org/10.1111/j.25176161.1975.tb01037.x

[9] Clarke RT. Statistical modelling in hydrology. Capítulo 7, Multivariate models, pp. 254-302, Chichester, Inglaterra, John Wiley \& Sons, 1994. 412.

[10] Ryan TP. Linear Regression, capítulo 14, pp. 14.1-14.43, en: Handbook of Statistical Methods for Engineers, Scientists, Harrison, M., Wadsworth, editor, 2a. ed., Nueva York, McGraw-Hill Book Co., 1998.

[11] Campos-Aranda D, Estimación simultánea de datos hidrológicos anuales faltantes en múltiples sitios, Ingeniería, Investigación y Tecnología. 2015; 16(2): 295306. https://doi.org/10.1016/j.riit.2015.03.013

[12] Oliver MA, Kriging: A Method of Interpolation for Geographical Information Systems, International Journal of Geographic Information Systems. 1990; 4: 313-332. 